\title{
NEW BIG WAR IN THE SOUTH CAUCASUS AND PROSPECTS FOR PEACE IN KARABAKH
}

Anar Valiyev*

ADA University, Baku

(c) A.Valiyev, 2020

\author{
Nargiz Gafarova** \\ ADA University, Baku
}

(C) N.Gafarova, 2020

DOI: 10.20542/2307-1494-2020-2-167-180

\begin{abstract}
The 2020 military escalation in Nagorno-Karabakh became the worst one since the 1994 ceasefire. The new war lasted over a month and resulted in more than 5,000 people dead and over 10,000 wounded from both sides. Meanwhile, South Caucasus occupies a specific place in the Russian foreign policy, due to Moscow's economic, political and military presence in the region. Moscow abstained from active involvement in the war, called for humanitarian ceasefire and for an end to hostilities and helped strike the November 10 ceasefire agreement. It seems that after the war Russia will need to deal with new situation in the South Caucasus, quite different from what it was before.
\end{abstract}

Keywords Nagorno-Karabakh conflict, Azerbaijan, Russian foreign policy, Turkey

Название Новая большая война на Южном Кавказе и перспективы мира в Карабахе статьи

Аннотация Военная эскалация в Нагорном Карабахе 2020 г. стала самой острой после прекращения огня в 1994 г. Новая война продолжалась более месяца и, по предварительным подсчетам, привела к потерям в более 5 тысяч убитыми и более 10 тысяч ранеными с обеих сторон. Между тем, в условиях экономического, политического и военного присутствия РФ в регионе, Южный Кавказ занимает особое место в российской внешней политике. Москва воздержалась от активного вмешательства в эту войну, призывала стороны к гуманитарному прекращению огня и прекращению военных действий и содействовала подписанию соглашению о перемирии от 10 ноября 2020 г. Представляется, что после войны России придется столкнуться с новой

\footnotetext{
* Anar Valiyev (Azerbaijan) is Associate Professor of the ADA University, Baku. Corresponding author: avaliyev@ada.edu.az.

Анар Валиев (Азербайджан) - доцент Университета ADA (Баку). Автор для корреспонденции: avaliyev@ada.edu.az.

${ }^{* *}$ Nargiz Gafarova (Azerbaijan) is a Research Fellow of the ADA University, Baku.

Наргиз Гафарова (Азербайджан) - научный сотрудник Университета ADA, Баку.
} 
ситуацией на Южном Кавказе, кардинально отличной от той, с которой она имела дело до этого.

Ключевые вооруженный конфликт в Нагорном Карабахе, Азербайджан, внешняя политика слова

России, Турция

\section{Introduction}

On September 27, 2020, the Azerbaijani ministry of defense reported that Armenian troops located in Karabakh shelled Azerbaijani villages. Following the reports of civilian deaths, Azerbaijan decided to launch a counter-offensive operation of its troops along the entire line of contact to suppress the combat activity of the armed forces of Armenia/Karabakh and ensure the safety of the civilian population. The military campaign has already been going on for more than a month. According to unconfirmed sources, by October 2020, the war claimed more than 5000 fatalities. Azerbaijani side claimed liberating 4 cities and over 200 villages. Three major powers - Russia, France, and the USA attempted to negotiate humanitarian ceasefire, but all such attempts failed until a trilateral agreement signed by Armenia, Azerbaijan and Russia at the night of 9-10 November 2020.

The start of major hostilities at the initial stage of this war took many scholars of the South Caucasus by surprise. They asked the same question "why now"? Azerbaijan's move was not unexpected - it was a question of time, particularly after Armenia's shelling of Tovuz city located outside Karabakh and had significant geostrategic importance. By then the same "why now?" question was asked, stemming from the general belief in that Armenia enjoyed the existing status quo. A range of possible explanations and interpretations from Azerbaijan's side included Nikol Pashinyan's attempt to consolidate his rule within the country and Armenia's perceived designs to threaten regional security at the intersection of energy and transportation roots (the latter, however, could not have been possible without Russia's knowledge, if not consent).

The changing situation prompted Azerbaijan to take a more active stance considering several factors. First, the war option has been voiced quite frequently by the Azerbaijani side for couple of decades, particularly after every new round of peace talks failed. Second, Azerbaijani statehood significantly consolidated since early 1990s and the Azerbaijani army was modernized and supplied with new weapons and equipment. Third, Baku lost its belief in the international community due to ineffectiveness of the Organization's for Security and Co-operation in Europe (OSCE's) Minsk Group (co-chaired by France, Russia and the USA) and to non-implementation of the UN Security Council's decisions recognizing the territorial integrity of Azerbaijan. Fourth, Turkey, who is the main ally and strategic partner of Azerbaijan, decided in favor of more active involvement in the crisis, following the Tovuz attack, and declared that it would back Azerbaijan up with all possible resources. Fifth, Russia seemed to hold back its support to Armenia, whose loyalty was questioned after Pashinyan's pro-Western statements, and to guarantee its non-intervention in the actual fighting on the Armenian side. Finally, it also seems that there might have been a tacit agreement between Turkey and Russia, assuming that the first plays an active role as a game changer and the latter then implicitly approves and helps to fix and normalize the situation. 
All of this found its proof on November 10, 2020. Presidents of Russia and Azerbaijan, and the Armenian prime minister, signed a joint statement. According to the statement, all hostilities were to be stopped. The agreement also envisaged the phased withdrawal of Armenian forces from those several occupied regions beyond Karabakh that Azerbaijani army could not liberate. In parts of Karabakh and along the critical Lachin corridor, they were to be replaced by the Russian peacekeepers (approximately 1960 people), to be initially deployed for a five-year period to prevent the hostilities and ensure the peace process. The agreement also made provisions concerning the return of refugees and internally displaced persons under the auspices of the UN High Commissioner for Refugees and the unblocking of the transport and economic routes in the region etc. For Azerbaijan, the November 10 deal was considered a victory, not in the least since the document did not mention any status of Karabakh thus confirming Azerbaijan's territorial integrity. Furthermore, within few months, a more comprehensive document should be signed to specify places of stationing of the Russian soldiers, timeline for return of refugees etc.

Overall, three countries - Azerbaijan, Russian, and Turkey - all won from the situation.

\section{Historical background}

In 1804-1829, as a result of several wars with Qajar and Ottoman empires, Russia conquered large parts of the South Caucasus, namely Erivan, Karabakh, Baku, Shirvan, Ganja, Sheki, Derbent, Talysh, and Nakhichevan khanates (territories of today's Azerbaijan and Armenia). Some khanates signed vassalage treaties. Azerbaijani khan of the Karabakh khanate Ibrahim Khalil and a representative of the Russian emperor General Pavel Tsitsianov signed a Treaty of Kurekchai, making the Karabakh khanate a protectorate of the Russian Empire. ${ }^{1}$ In 1918, three South Caucasian republics - Azerbaijan, Armenia, and Georgia - became independent after the collapse of the Russian Empire. The Karabakh and Zangezur regions were administered by Azerbaijani General Governor Khosrov Sultanov. In 1919, the Karabakh Armenians agreed to submit to provisional Azerbaijani rule in the region in exchange for their cultural and civic rights. In June 1921, the Bolsheviks handed over Zangezur to Armenia by a secret decision. ${ }^{2}$ A month later, members of the Soviet Caucasian Bureau, including Josef Stalin, gathered in Tbilisi to discuss the issue of the mountainous part of Karabakh. Their decision was to "include" (vklyuchit') mountainous Karabakh into Armenia. Azerbaijani communist leader Nariman Narimanov strongly objected to the decision and demanded the issue to be brought to the Central Committee of the Russian Communist Party. This demand was satisfied by the Caucasian Bureau. Stalin himself did not vote, as he was not a member of the Caucasian Bureau. ${ }^{3}$ During the next day, the Caucasian Bureau continued the discussion and this time their decision was the opposite to retain (ostavit') the mountainous part of Karabakh in Azerbaijan. ${ }^{4}$ Among those who supported this decision were several Bureau's members of the Armenian origin.

(a) The first stage of the conflict

The contemporary phase of the Armenia-Azerbaijan conflict over the NagornoKarabakh region of Azerbaijan began in February 1988, with the Armenian nationalists' demand for unification (miatsum in Armenian) with Armenia. On 20 February 1988, Armenian deputies of the National Council of Nagorno-Karabakh voted for incorporating 
Nagorno-Karabakh into Armenia, in violation of the Azerbaijani and the Soviet laws. On February 24, 1988, two young Azerbaijanis, killed in the settlement of Askeran in Nagorno-Karabakh during the stand-off between Armenian and Azerbaijani demonstrators, became the first victims of the conflict. On February 26-28, violent clashes in the Azerbaijani city of Sumgayit resulted in 26 Armenian and six Azerbaijani fatalities. As tensions mounted, over 200000 Azerbaijanis were expelled from Armenia. Then, the Soviet authorities introduced curfew. On December 1, 1989, the parliament of Soviet Armenia passed a bill authorizing integration of Nagorno-Karabakh with Armenia. The central Soviet authorities in Moscow nullified the decision, but this move by Armenian side added tension to the evolving conflict. On September 2, 1991, "the local councils" of Nagorno-Karabakh adopted a "Declaration of Independence of the Republic of Nagorno-Karabakh".

\section{Map 1. Nagorno-Karabakh and adjacent occupied territories}

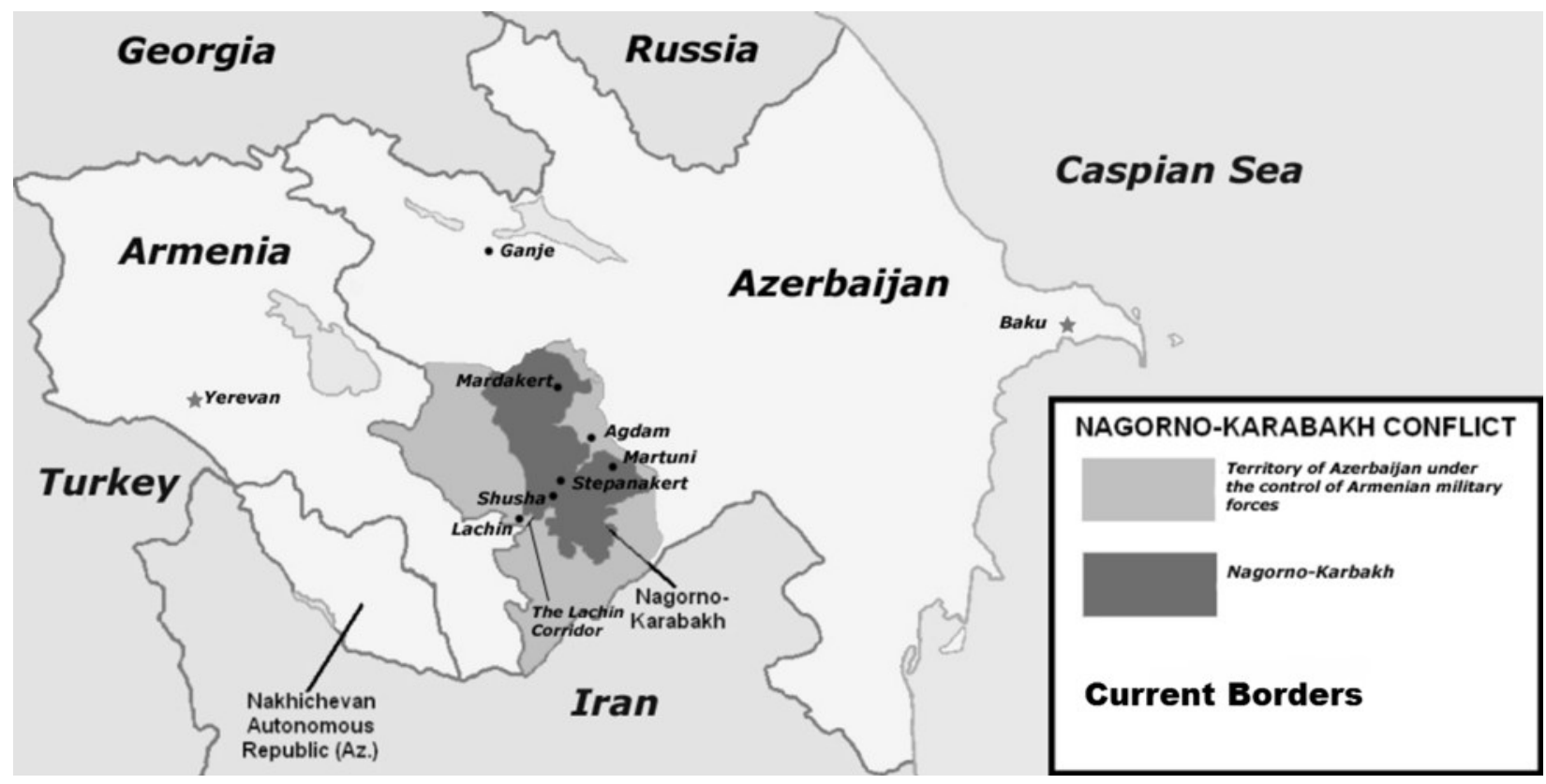

Source: Wikimedia Commons. Map author: Author: Achemish.

URL: https://commons.wikimedia.org/wiki/File:Nagorno-Karabakh_Map2.png.

After the collapse of the Soviet Union, Armenia launched full-scale armed hostilities against Azerbaijan in Nagorno-Karabakh. Armenian forces defeated Azerbaijani forces entangled in internal fight for power and then occupied seven regions outside NagornoKarabakh. On February 25-26, 1992 Armenian armed forces razed the Azerbaijani town of Khojaly to the ground, killing 613 Azerbaijanis. In May 1992, Armenian armed forces captured Shusha (a strategically important city in Nagorno-Karabakh populated mostly by ethnic Azerbaijanis) and later Lachin. After short advancement of Azerbaijanis in summer 1992, successful Armenian offensive resulted in the occupation of Kelbajar, Agdam, Fizuli, Jabrail, Qubadli, and Zangezur in 1993. During the same year, the UN Security Council

\footnotetext{
* This map is distributed under the Creative Commons license and is not covered by the Copyright license applicable to this article.
} 
adopted four resolutions $-822,853,874$, and 884 , - demanding the withdrawal of Armenian troops from the occupied Azerbaijani territories and reconfirming Azerbaijan's sovereignty over the Nagorno-Karabakh region. In May 1994, Russia brokered a cease-fire agreement in Bishkek, Kyrgyzstan.

\section{(b) The negotiation process}

After both Armenia and Azerbaijan were admitted as members to the Conference on Security and Co-operation in Europe (CSCE) in 1992, the organization launched its conflict resolution initiatives. After the Khojaly massacre on February 26, 1992, the CSCE intensified its involvement in the conflict, which led to the March 24, 1992 decision of the CSCE's Ministerial Council to convene a conference in Minsk to work on the final settlement of the conflict. ${ }^{5}$ However, essential contradictions between the two parties of the conflict, as well as a limited effectiveness of the conference format, led to the replacement of the Minsk Conference idea with the "Minsk Group". ${ }^{6}$ During the CSCE Budapest Summit held in December 1994, the participating states declared their commitment to the four aforementioned UN Security Council resolutions on the Armenia-Azerbaijan conflict and decided to send the first multinational force to the region. The Budapest Summit therefore authorized the establishment of the High-Level Planning Group (HLPG). ${ }^{7}$ On March 23 , 1995, the mandate of the Minsk Group's co-chairs was adopted, and by 1997 three cochairs - the USA, Russia, and France - were engaged in mediation between the parties. ${ }^{8}$

At the OSCE Lisbon Summit in 1996, three key principles were laid out as legal basis for the peaceful settlement:

- Territorial integrity of the Republic of Armenia and the Republic of Azerbaijan;

- Legal status of Nagorno-Karabakh defined in an agreement based on self-determination that confers on Nagorno-Karabakh the highest degree of self-rule within Azerbaijan;

- Guaranteed security for Nagorno-Karabakh and its population, including mutual obligations to ensure the compliance by other parties with the provisions of the settlement. ${ }^{9}$

In November 2007, on the margins of the Fifteenth Meeting of the Foreign Ministers of the OSCE, the "Madrid Principles" were presented by the co-chairs to the parties. These principles were a slightly revised version of the basic principles submitted in 2006. "Madrid Principles", updated in 2009, were based on a compromise. This compromise envisaged withdrawal of the Armenian forces from the occupied territories adjacent to the NagornoKarabakh region (with special modalities for the Lachin and Kelbajar districts) and subsequent establishment of interim international security arrangements for the region until the vote on the status is conducted. ${ }^{10}$ Since initiation of the Madrid principles, direct negotiations continued, with Russia as the main mediator of the meeting between the parties. From 2009-2011, the OSCE Minsk Group Co-Chairs were also engaged in shuttle diplomacy between the conflicting parties. Three joint statements on Nagorno-Karabakh conflict were issued by the leaders of the OSCE Minsk Group's co-chair countries at the L'Aquila G8 Summit in Italy in July 2009, at the Muskoka G8 Summit in Canada in June 2010, and at the Deauville G8 Summit in France in May 2011. During the latter summit, leaders of the Co-Chair countries reaffirmed their commitment to support the leaders of Armenia and Azerbaijan in their efforts to finalize the Basic Principles for the peaceful settlement of the Nagorno-Karabakh conflict. ${ }^{11}$ 
After a long hiatus in negotiations, following the January 2012 meeting between the presidents of Armenia and Azerbaijan in Sochi (Russia), the next meeting of the presidents took place in Vienna in October 2013 under mediation of the OSCE Minsk Group's cochairs. These negotiations, however, did not produce any results. In 2014, there were meetings in Sochi (August), on the margins of the NATO's Wales Summit (September 2014), and in Paris (October 2014). In Paris, the presidents agreed to exchange information under the auspices of the International Committee of the Red Cross on the missing persons in the Armenia-Azerbaijan conflict. Later, the parties also met in September 2015 on the margins of the UN General Assembly, in May 2016 (Vienna), in June 2016 (St Petersburg), in October 2017 (Geneva), and in December 2017 (Vienna).

This period, however, was also marked by the growing number of incidents on the frontline. These incidents culminated in the "four-day war" in April 2016, when Azerbaijan responded to the Armenian provocations at the frontline. The change in the Armenian leadership that occurred in spring of 2018 brought up the hopes that new energy and dynamics could be infused into the negotiations. However, the new prime minister-elect of Armenia, Nikol Pashinyan, in his controversial speech on August 5, 2019, given during the pan-Armenian games held in Khankendi, took the liberty to declare that "Karabakh is Armenia, period!" This hostile move by Armenia's Prime-Minister was soon rebuffed by Azerbaijani President Ilham Aliyev during his speech at Valdai discussion club on October 3, 2019. He declared that "Karabakh is Azerbaijan and exclamation mark!" November 2019, however, was marked by such a positive event as the journalist exchange facilitated by the OSCE Minsk Group: three journalists from Azerbaijan visited Armenia and the Nagorno-Karabakh region, while three journalists from Armenia visited Azerbaijan.

Nevertheless, the negotiation process remained firmly stagnant, despite the positive dynamics in the frequency of meetings between the parties in 2019. This lack of progress in the peace talks was characterized by the President of Azerbaijan Ilham Aliyev as the "lost year for the negotiation process". ${ }^{12}$

\section{The run-up to the Big War: the July 2020 clashes}

One of the most significant events of 2020 was military clashes on the Azerbaijan's border with Armenia. On July 12-14, Armenian and Azerbaijani military forces clashed at the junction of the Tovuz region of Azerbaijan and the Tavush region of Armenia. This was one of the largest and deadliest confrontations since the April 2016 escalation. ${ }^{13}$ Within a few days, 12 Azerbaijanis, including one civilian and a high-ranking officer, were killed, while the Armenian side reported four dead soldiers. It is difficult to establish with accuracy what caused the hostilities in the southwest of Azerbaijan, two hundred kilometers from Karabakh. ${ }^{14}$ Both sides accused each other in escalation, coming up with various explanations and conspiracy theories. In early August, Russian foreign minister Lavrov stated in an interview that the reason behind the skirmishes was a decision of the Armenian side to restore the old border checkpoint located 15 kilometers from the Azerbaijani export pipelines, which ignited heightened anxiety of Azerbaijan and led to disproportional response. ${ }^{15} \mathrm{He}$ also stated that the ceasefire was reached through the active Russian mediation. Indeed, the area of hostilities is a strategically important region of Azerbaijan, through which the Baku-Tbilisi-Ceyhan oil pipeline and the Baku-TbilisiErzurum gas pipeline, as well as the South Caucasus pipeline (the first segment of the 
international Southern Gas Corridor gas mega-route), are passing. The clashes also sparked the rise of nationalism and patriotism in Baku that resulted in street demonstrations and unprecedented pressure on the government to continue further military actions to regain the occupied territories in Karabakh.

Several explanations for the outburst of the conflict were circulating in Azerbaijan. One of the most popular ones implied an Armenian "plot" to push Azerbaijan for making concessions on Nagorno-Karabakh by threatening to destroy the Azerbaijani energy infrastructure. Azerbaijan has already launched the TANAP/TAP gas pipeline (TransAnatolian Pipeline and Trans-Adriatic Pipeline) that would deliver its gas to the Bulgarian, Italian, Greek and Turkish markets and would further decrease the dependence of the EU states on the Russian gas. As of March 2020, the pipeline gas import of Turkey was 1.8 billion cubic meters $(\mathrm{bcm})$, of which the lion's share was accounted for by Azerbaijan $(0.924 \mathrm{bcm})$, while the rest was provided by Iran $(0.557 \mathrm{bcm})$ and Russia $(0.389 \mathrm{bcm})$. Overall, gas import from Russia was down by $72 \%$, as compared with March $2019 .{ }^{16}$

Table 1. Major pipelines delivering gas and oil from Azerbaijan to Europe

\begin{tabular}{|c|c|}
\hline Pipeline & Description \\
\hline $\begin{array}{l}\text { Southern Gas } \\
\text { Corridor (SGC) }\end{array}$ & $\begin{array}{l}\text { SGC is a term used to describe almost completed infrastructure projects } \\
\text { aimed at improving security and diversity of the EU's energy supply by } \\
\text { bringing natural gas from the Caspian region to Europe. Stretching over } \\
3500 \text { kilometers, crossing seven countries, and involving more than a } \\
\text { dozen major energy companies, it comprises the four major segments, the } \\
\text { total investments for which amounts to approximately } 40 \text { billion USD. The } \\
\text { corridor includes South Caucasus Pipeline (SCP) that was built to export } \\
\text { Azerbaijani gas to Georgia and Turkey. The next part of SGC is the Trans- } \\
\text { Anatolian Pipeline (TANAP). TANAP is directly connected to SCP at the } \\
\text { Georgia-Turkey border and to the Trans-Adriatic Pipeline at the Turkey- } \\
\text { Greece border. The Trans-Adriatic Pipeline (TAP) connects with TANAP } \\
\text { at the Greece-Turkish border. TAP crosses Northern Greece, Albania, and } \\
\text { the Adriatic Sea before coming ashore in Southern Italy to connect to the } \\
\text { Italian natural gas network. }\end{array}$ \\
\hline $\begin{array}{l}\text { Baku-Novorossiysk } \\
\text { oil pipeline }\end{array}$ & $\begin{array}{l}\text { The pipeline transports oil from Azerbaijan to the Russian port of } \\
\text { Novorossiysk on the Black Sea. The transmission capacity of this pipeline } \\
\text { is } 100000 \text { barrels per day (bpd). Most of the time, Baku prefers pumping } \\
\text { oil through other pipelines, thus making Baku-Novorossiysk not } \\
\text { operational. }\end{array}$ \\
\hline $\begin{array}{l}\text { Baku-Supsa oil } \\
\text { pipeline }\end{array}$ & $\begin{array}{l}\text { The Baku-Supsa Pipeline, or the Western Route Export Pipeline (WREP), } \\
\text { transports crude oil from offshore oil fields from within the Azerbaijani } \\
\text { offshore Caspian Sea deposits to the European markets through Georgia. } \\
\text { Crude oil is shipped via tankers, loaded at the Supsa terminal in Georgia, } \\
\text { and then makes its way through the Bosporus to Europe. The } \\
\text { transmission capacity of the pipeline is } 150000 \text { bpd. }\end{array}$ \\
\hline $\begin{array}{l}\text { Baku-Tbilisi-Ceyhan } \\
\text { oil pipeline }\end{array}$ & $\begin{array}{l}\text { The pipeline is a major transportation route for the Caspian oil to reach the } \\
\text { world markets. Its total length is } 1768 \mathrm{~km} \text { and runs through the territory of } \\
\text { three countries: Azerbaijan }(443 \mathrm{~km}) \text {, Georgia }(249 \mathrm{~km}) \text {, and Turkey } \\
(1076 \mathrm{~km}) \text {. The transmission capacity of this pipeline is } 1.2 \text { million bpd } \\
\text { and can be expanded further. }\end{array}$ \\
\hline
\end{tabular}




\section{Map 2. The Southern Gas Corridor}

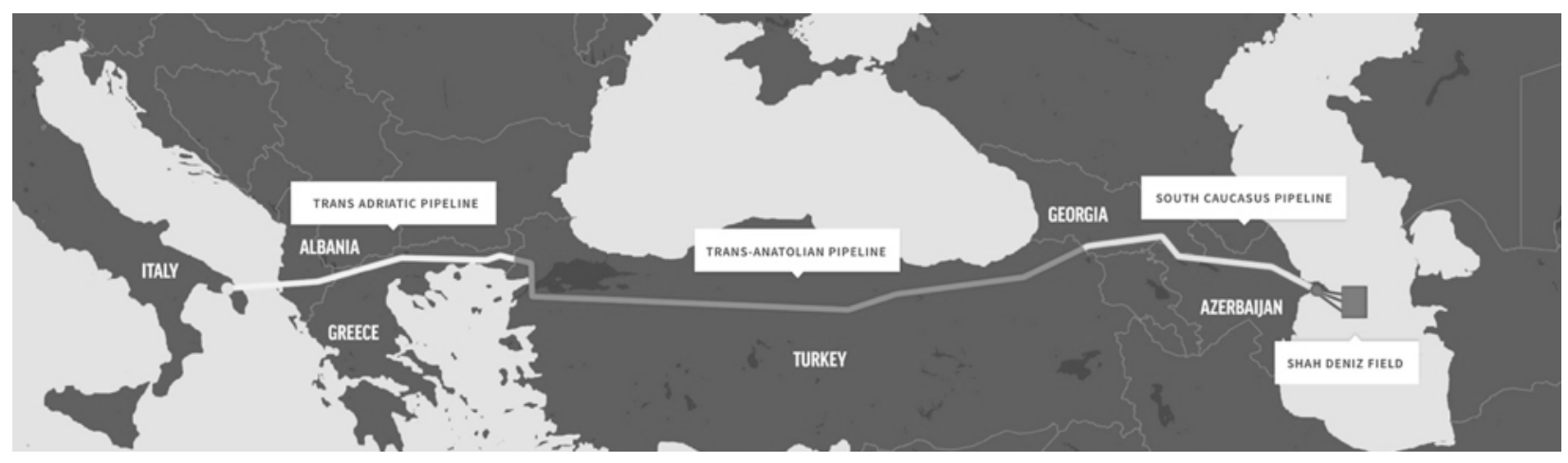

Source: Southern Gas Corridor [Official web-site].

URL: https://www.sgc.az/media/images/map-en.jpg.

\section{Map 3. The map of existing pipelines ${ }^{*}$}

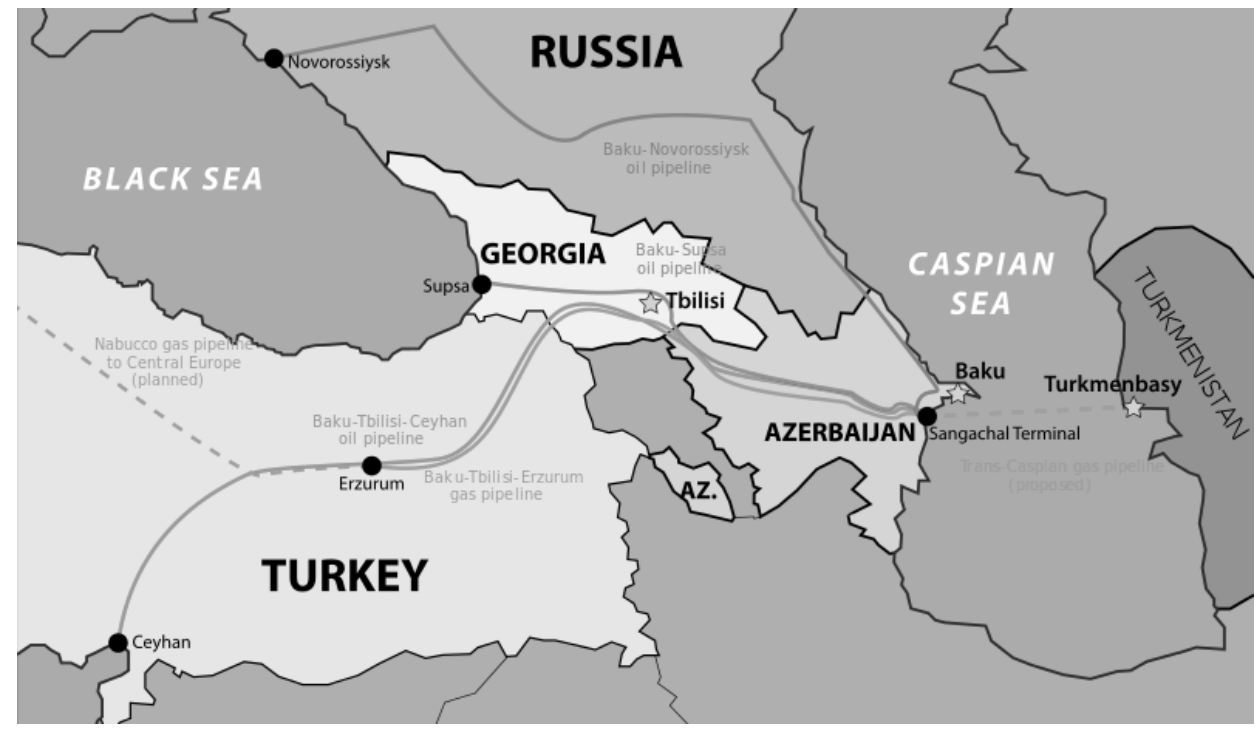

Source: Wikimedia Commons. Map author: Thomas Blomberg.

URL: https://commons.wikimedia.org/wiki/File:Baku_pipelines.svg

The fact that the Armenian attack on Azerbaijan happened in the Tovuz region outside Nagorno-Karabakh indicated that the logic behind it was likely not to have full-scale conflict, but to demonstrate power instead. Mr. Elshad Nasirov, Vice-President for State Oil Company (SOCAR) of Azerbaijan, pointed out that Baku-Tbilisi-Ceyhan, the Southern Gas Corridor, the Baku-Supsa pipeline, the Baku-Tbilisi-Kars railway, and the Baku-Tbilisi highway were all close to the place of the outbreak of hostilities. "I want everyone ... to think

* This map is distributed under the Creative Commons license and is not covered by the Copyright license applicable to this article. 
about how fragile the pipeline corridor and the Trans-Caspian region are and how to provide military and physical security to the corridor that provides energy security to Europe". ${ }^{17}$ Some military experts also argued that clashes between Armenia and Azerbaijan targeted the high ground that would allow Armenia to hamper oil and gas deliveries communications, as well as the Baku-Tbilisi-Kars railway. ${ }^{18}$ For Moscow, it is very important to control and disrupt such communications, especially in view of Turkmenistan's interest to join the TANAP project through the projected Trans-Caspian Pipeline. It is not a coincidence that, in March 2020, the Turkmen president visited Baku where he discussed with the Azerbaijani leadership further joint development and implementation of energy projects. Construction of a pipeline for exporting Turkmen and Azerbaijani gas westwards is one of such prospective projects. ${ }^{19}$ If it is implemented, Turkmen and Azerbaijani gas would make around $10 \%$ of the EU's total annual gas supply.

Russia brokered a short-lived ceasefire in July, but was perceived negatively by some in Azerbaijan. During clashes in the Tovuz region, Azerbaijan claimed that Russia supplied arms to Armenia. These accusations came during the large-scale exercises "Caucasus2020" held by Russia jointly with Armenia. Some Azerbaijani governmental mass media leaked the news that several tons of weapons were shipped from Russia to Armenia between July 17 and August 4, replenishing Yerevan's arm stock that was depleted during the clashes with Azerbaijan back in July. On August 13, 2020, presidents of Azerbaijan and Russia discussed this issue on the phone and the Azerbaijani president raised serious concerns and questions about it. ${ }^{20}$ Government mass media used harsh tone in their reports claiming that weapons were delivered to Armenia not only after the clashes, but right on the eve of them. Some tracked flights from the Russian city of Rostov-on-Don to Armenia's capital of Yerevan over southern Russia, Kazakhstan, the Caspian Sea, and Iran. ${ }^{21}$ Azerbaijani mass media claimed that weapons delivery prompted Armenia to go for provocation. ${ }^{22}$ Harsh criticism of the Russian involvement could be considered as Azerbaijani leverage vis-a-vis Russia and this tactic worked. Moscow dispatched to Baku its Defense Minister, Sergei Shoigu, who tried to assure President Aliyev of the routine character of military supply deliveries. During the meeting, President Aliyev suggested that the purpose of the Armenian provocation was to drag the Collective Security Treaty Organization (CSTO) into the Armenia-Azerbaijan conflict. He also stated that the intensity of the Russian military supplies to Armenia "caused concern and serious questions among

the wider Azerbaijani public". ${ }^{23}$ Some weeks after, presidential foreign advisor Hikmet Hajiyev reiterated accusations and expressed the government's opinion that the official Russian explanation of arms supply to Armenia during the conflict was not satisfactory. ${ }^{24}$

\section{What is next after Karabakh?}

As of the late 2020, it seems that the conflict in Karabakh may now be resolved within a relatively short period. Without outside intervention, Karabakh and Armenia would lose any war and would need to evacuate its troops from Karabakh. Hence, Azerbaijan will be able to restore its sovereignty over the territory. Meanwhile, analysts pose and try to answer some important questions. Why did Russia not intervene into the conflict and did not support its CSTO ally Armenia? Why did Moscow choose to keep its neutrality (a move that was considered to benefit Azerbaijan)? 
Throughout the modern history, the Azerbaijani foreign policy towards Russia has been driven by two constant determinants. On the one hand, Russia's continued support to Armenia and its procrastination in the resolution of the Nagorno-Karabakh conflict have prevented Azerbaijan from active rapprochement with the West. Russia appeared to believe that if the Nagorno-Karabakh conflict is genuinely solved, Baku would immediately rush into anti-Russian alliances such as NATO. Unresolved Nagorno-Karabakh conflict has thus remained the key leverage that Russia could use against Azerbaijan to keep the latter from unfriendly actions. The 2008 Russia-Georgia War, as well as Russia's annexation of the Crimea and its support for separatists in the Donbas, further complicated Azerbaijan's position in this respect.

At the same time, Azerbaijan's vast oil and gas reserves encouraged Baku to stress the rhetoric of independence in its foreign policy. The country steadily built up its geostrategic importance by contributing to Europe's energy security, that allowed Baku to avoid turning into a "Kremlin's puppet". It was the "blessing" of natural resources that provided Azerbaijan with another option for adjusting its relations with Russia as a great power - an alternative to either counterbalancing, or bandwagoning. Availability of a middle ground and strategic hedging became the basis for Baku's foreign policy stance. It allowed Azerbaijan to strengthen its strategic positions in the regional system, on the one hand, and to ease tensions in the regional environment, on the other hand. Azerbaijan's strategic hedging vis-à-vis Moscow has, therefore, allowed Baku to avoid entanglement in contestation between major powers that could endanger its autonomy. Such entanglement would be inevitable if Azerbaijan would adhere to the traditional one-sided strategic alignment choices by either counterbalancing Russia, or bandwagoning with it.

However, in 2020, the situation has changed. The looming prospect of imminent war with Armenia (that enjoys Russian support) has forced Azerbaijan to rely more on its traditional ally - Turkey. To illustrate importance of the Turkish support, an earlier example from Azerbaijani modern history can be used. In the early 2000 s, Iranian military planes were constantly violating Azerbaijan's air space. After Baku called for the Turkish support, Turkey held the military exercise in Azerbaijan and sent strong signals to Iran. This time, while Russia supported Armenia, Baku also hosted joint Azerbaijani-Turkish military exercises in the Azerbaijani exclave of Nakhichevan and in other parts of the country on July 29 - August 6, 2020. High-ranking Turkish military officials, including Minister of National Defense Hulusi Akar, Chief of the General Staff of the Turkish Armed Forces, Army General Yashar Guler, and other senior officers, paid visits to Baku. ${ }^{25}$ During his meetings with Turkish military officials, President Aliyev stated that Turkey would become number one partner of Azerbaijan in military-technical cooperation, while for many years Russia was the largest arms exporter to Azerbaijan. Furthermore, Minister Akar assured that the Turkish military power will be lent in support of Azerbaijan in its opposition with Armenia. ${ }^{26}$ It is worth mentioning that the Turkish rhetoric and support were much stronger than before. Turkey also promised to accelerate its arms supply and provide Azerbaijan with high-tech arms, including deadly drones that have been effectively used by Turkish militaries in Libya, Syria, and Iraq.

Azerbaijan's growing inclination towards Turkey should worry Moscow. The Kremlin could be prompted to act fast using a typical "stick and carrots" policy toward Azerbaijan. This time, however, it would be difficult for Moscow to persuade Baku in its neutrality. Experts believe that Moscow and Ankara may revive some initiatives that were launched 
back at the time of the 2008 Russia-Georgia crisis. The new scheme "Russia + Armenia vs. Turkey + Azerbaijan" was spelled out to test the broader international reaction. Such a platform would allow Russia and Turkey to become guarantors of the future peace treaty between Armenia and Azerbaijan. However, it could be problematic, in view of the Armenian distrust of the Turkish plans in the Caucasus, as well as the Ankara-Moscow controversies in other parts of the world. ${ }^{27}$

At present, neither the United States, nor the EU enjoy the same degree of leverage in the South Caucasus as Russia does. Moscow has a military presence in Armenia (a military base in Gyumri), strong economic position in Armenia and Georgia, as well as extensive soft power in Azerbaijan (e. g. media, culture, Russian language schools, and a university). Moreover, Russian political figures frequently visit Baku, and the Russian political establishment has plans for close cooperation with Azerbaijan. Baku-Moscow military cooperation has also grown significantly. Thus, Moscow's neutrality serves the purpose to win Azerbaijan back.

The mediation by the Russian president came exactly at the right time. It allowed Azerbaijan to free big chunk of Azerbaijani territory without fighting. Also, the presence of the Russian troops on Armenian side of border would not let the border between two countries to become similar to the India-Pakistan border, with constant shelling and deadly exchanges. Finally, the Russian presence, as well as the Turkish involvement, would allow Karabakh to become the place of cooperation between Russia, Azerbaijan and Turkey rather than a bone of contention.

\section{Conclusion}

It is expected that the region of South Caucasus in general, and Azerbaijan in particular, become a place where interests of Russia and Turkey would concur rather than collide. Baku will continue to be an important energy supplier for Europe and will further expand its gas pipeline network to Turkmenistan, while taking into consideration the Russian interests. The resolution of the Karabakh conflict will bring both Russian and Turkish companies into the region for reconstruction and will open new business opportunities for all sides involved. Finally, the Russian soft power may actually grow in the region, while Karabakh can serve as positive example of the new Russian foreign policy doctrine, winning the hearts and minds of post-Soviet countries.

\section{ENDNOTES}

\footnotetext{
${ }^{1}$ The Agreement Between the Khan of Karabakh and the Russian Empire on Placing the Karabakh Khanate Under the Authority of Russia. 14 May 1805.

2 Российский государственный архив социально-политической истории (РГАСПИ) [Russian State Archive of Social-Political History]. Ф. 64. Оп. 1. Д. 1. С. 76-77.

${ }^{3}$ Там же. Ф. 64. Оп. 1. Д. 1. С. 118.

${ }^{4}$ Там же. Ф. 64. Оп. 1. Д. 215. С. 118.
} 
${ }^{5}$ OSCE Handbook. Ed. W.Kemp. - Vienna: OSCE Secretariat, 2000. P. 65.

${ }^{6}$ At the beginning, the Minsk Group consisted of nine participating states only. Armenia and Azerbaijan joined the group later in the year. Currently, the Minsk Conference consists of 14 states. 11 permanent members are Armenia, Azerbaijan, Belarus, Finland, France, Germany, Italy, Russia, Sweden, Turkey, and the USA. The OSCE Troika (the Chairman-in-Office, the previous and succeeding chairpersons) is formed by members on the rotating basis.

${ }^{7}$ OSCE Handbook. Ibid.

${ }^{8}$ Mandate of the Co-Chairmen of the Conference on Nagorno Karabakh under the auspices of the OSCE ("Minsk Conference"). OSCE DOC. 525/95. Vienna, 23 March 1995. URL: https://www.europarl.europa.eu/meetdocs/2009_ 2014/documents/afet/dv/201/201106/20110615_mandateoscemg_en.pdf.

${ }^{9}$ Statement of the OSCE Chairman-in-Office on the Nagorno-Karabakh Conflict. 2-3 December 1996. OSCE Lisbon Summit 1996. Annex 1 of the Lisbon Document. URL: https://www.allgeo.org/index.php/en/1927-statement-ofthe-osce-chairman-in-office-on-the-nagorno-karabakh-conflict-2-3-december-1996.

${ }^{10}$ Nagorno-Karabakh: Risking War. International Crisis Group (ICG) Europe Report № 187. 14 November 2007. Tbilisi; Brussels: ICG, 2007. URL: https://www.crisisgroup.org/europe-central-asia/caucasus/nagorno-karabakhazerbaijan/nagorno-karabakh-risking-war; Armenia and Azerbaijan: Season of Risks. ICG Europe Briefing № 71. 26 September 2013. -Baku; Yerevan; Tbilisi; Brussels: ICG, 2013. URL: https://www.crisisgroup.org/europe-centralasia/caucasus/armenia/armenia-and-azerbaijan-season-risks.

${ }^{11}$ Joint Statement on the Nagorno-Karabakh Conflict by U.S. President Obama, Russian President Medvedev, and French President Sarkozy at the L'Aquila Summit of the Eight, July 10, 2009. Office of the Press Secretary, The White House. URL: https://obamawhitehouse.archives.gov/the-press-office/joint-statement-nagorno-karabakh-conflict; G8 Summit: Joint Statement on the Nagorno-Karabakh Conflict by Dmitriy Medvedev, President of the Russian Federation, Barack Obama, President of the United States of America, and the Nicolas Sarkozy, President of the French Republic. 26 June 2010. URL: https://obamawhitehouse.archives.gov/the-press-office/g8-summit-jointstatement-nagorno-karabakh-conflict-dmitry-medvedev-president-russi; Joint Statement on the Nagorno-Karabakh Conflict by the Presidents of the OSCE Minsk Group Co-Chair Countries at the G8 Summit. May 16, 2011. URL: http://www.osce.org/mg/78195.

12 Mehdiyev M. President Aliyev calls 2019 "a lost year" for Nagorno-Karabakh negotiations" // Caspian News. 26.12.2019. URL: https://caspiannews.com/news-detail/president-aliyev-calls-2019-a-lost-year-for-nagornokarabakh-negotiations-2019-12-25-10.

${ }^{13}$ Garibov A. What is new in the latest Armenian-Azerbaijani conflict escalation? // Eurasia Daily Monitor. V. 17. № 105. 2020. URL: https://webcache.googleusercontent.com/search?q=cache:rR-bfb091kQJ:https://jamestown. org/program/what-is-new-in-the-latest-armenian-azerbaijani-conflict-escalation/+\&cd=1\&hl=ru\&ct=clnk\&gl=ru.

${ }^{14}$ International Crisis Group report published right after the incident remains one of the neutral accounts of these events. See: Preventing a Bloody Harvest on the Armenia-Azerbaijan State Border. ICG Europe Report № 259. 24 July 2020. - Brussels: ICG, 2020. URL: https://www.crisisgroup.org/europe-central-asia/caucasus/nagornokarabakh-conflict/259-preventing-bloody-harvest-armenia-azerbaijan-state-border.

${ }^{15}$ Морозов М. Сергей Лавров: пандемия ускорила мыслительные процессы в Евросоюзе // Труд. 20.08.2020.

${ }^{16}$ Russian share of gas imports falls as Turkey turns to cheaper LNG // Daily Sabah. 05.06.2020. URL: https://www.dailysabah.com/business/energy/russian-share-of-gas-imports-falls-as-turkey-turns-to-cheaperIng. Moreover, the Russian exports to Greece and Bulgaria dropped $12.7 \%$ and $17.4 \%$ respectively, as shown by Russia's "Gazprom" data. The main reason was in low liquefied natural gas (LNG) prices, driven down by low 
demand in Asia and by expansion of gas output from Azerbaijan and its pipeline's capacity. Retrieved from: Gazprom PAO GAZP.MM // Reuters. URL: https://uk.reuters.com/companies/GAZP.MM.

${ }^{17}$ Elshad Nasirov: Armenian provocation is a threat to Azerbaijan's energy infrastructure // Azerbaycan 24. 17.07.2020. URL: https://www.azerbaycan24.com/en/elshad-nasirov-armenian-provocation-is-a-threat-toazerbaijan-s-energy-infrastructure.

${ }^{18}$ Interview with an anonymous military expert. 2 August 2020.

${ }^{19}$ Saeedi T. Turkmenistan-Azerbaijan partnership acquires additional features // News Central Asia. 12.03.2020. URL: http://www.newscentralasia.net/2020/03/12/turkmenistan-azerbaijan-partnership-acquires-additionalfeatures.

${ }^{20}$ Mammadov A. President Aliyev voices concerns over military cargo delivery to Armenia in phone call to Putin // Azernews. 13.08.2020. URL: https://www.azernews.az/nation/167949.html.

${ }^{21}$ В дни боев в Товузе в Армению поставляли оружие из России // News.az. 07.08.2020. URL: https://news.day.az/politics/1260479.html.

${ }^{22}$ Хроника лавирующего IL-76 // Minval.az. URL: https://minval.az/news/124017771.

${ }^{23}$ Mammadov Z. How to understand the fact that the co-chair Russia arms the aggressor - Armenia? // APA. 13.08.2020. URL: https://apa.az/en/politics_of_azerbaijan/How-to-understand-the-fact-that-the-co-chair-Russiaarms-the-aggressor-Armenia-colorredANALYSIScolor-327945.

${ }^{24}$ Baku made it clear: it will not allow to make idiot of itself // Turan.az. 29.08.2020.

URL: https://turan.az/ext/news/2020/8/free/politics\%20news/en/127125.htm.

${ }^{25}$ Turkish high-ranked military officials arriving in Azerbaijan to observe joint tactical exercises // Trend. 12.08.2020. URL: https://en.trend.az/azerbaijan/politics/3283436.html

${ }^{26}$ Турция станет партнером № 1 Азербайджана в области BTC // Turan. 13.08.2020.

URL: https://turan.az/ext/news/2020/8/free/politics\%20news/ru/126641.htm.

${ }^{27}$ Interview with an anonymous expert. 8 August 2020.

\section{БИБЛИОГРАФИЯ/BIBLIOGRAPHY}

1. Armenia and Azerbaijan: Season of Risks. International Crisis Group (ICG) Europe Briefing № 71. Baku; Yerevan; Tbilisi; Brussels: ICG, 2013. URL: https://www.crisisgroup.org/europe-centralasia/caucasus/armenia/armenia-and-azerbaijan-season-risks.

2. Mandate of the Co-Chairmen of the Conference on Nagorno Karabakh under the auspices of the OSCE ("Minsk Conference"). OSCE DOC. 525/95. Vienna, 23 March 1995.

URL: https://www.europarl.europa.eu/meetdocs/2009_2014/documents/afet/dv/201/201106/ 20110615_mandateoscemg_en.pdf.

3. G8 Summit: Joint Statement on the Nagorno-Karabakh Conflict by Dmitriy Medvedev, President of the Russian Federation, Barack Obama, President of the United States of America, and the Nicolas Sarkozy, President of the French Republic. 26 June 2010. URL: https://obamawhitehouse. archives.gov/the-press-office/g8-summit-joint-statement-nagorno-karabakh-conflict-dmitry-medvedevpresident-russi.

4. Garibov A. What is new in the latest Armenian-Azerbaijani conflict escalation? // Eurasia Daily Monitor. V. 17. № 105. 2020. URL: https://webcache.googleusercontent.com/search?q=cache:rR- 
bfbO91kQJ:https://jamestown.org/program/what-is-new-in-the-latest-armenian-azerbaijani-conflictescalation $/+\& c d=1 \& h l=r u \& c t=c l n k \& g l=r u$.

5. Gazprom PAO GAZP.MM // Reuters. URL: https://uk.reuters.com/companies/GAZP.MM.

6. Joint Statement on the Nagorno-Karabakh Conflict by U.S. President Obama, Russian President Medvedev, and French President Sarkozy at the L'Aquila Summit of the Eight, July 10, 2009. Office of the Press Secretary, The White House. URL: https://obamawhitehouse.archives.gov/the-pressoffice/joint-statement-nagorno-karabakh-conflict.

7. Mammadov A. President Aliyev voices concerns over military cargo delivery to Armenia in phone call to Putin // Azernews. 13.08.2020. URL: https://www.azernews.az/nation/167949.html.

8. Mammadov Z. How to understand the fact that the co-chair Russia arms the aggressor - Armenia? // APA. 13.08.2020. URL: https://apa.az/en/politics_of_azerbaijan/How-to-understand-the-fact-that-theco-chair-Russia-arms-the-aggressor-Armenia-colorredANALYSIScolor-327945.

9. Mehdiyev M. President Aliyev calls 2019 "A lost year" for Nagorno-Karabakh negotiations // Caspian News. 26.12.2019. URL: https://caspiannews.com/news-detail/president-aliyev-calls-2019-a-lostyear-for-nagorno-karabakh-negotiations-2019-12-25-10.

10. Morozov M. Sergei Lavrov: Pandemiya uskorila myslitelnyie protsessy v Evrosoyuze // Trud. 20.08.2020.

Морозов М. Сергей Лавров: пандемия ускорила мыслительные процессы в Евросоюзе // Труд. 20.08.2020.

11. Nagorno-Karabakh: Risking War. ICG Europe Report № 187. - Tbilisi; Brussels: ICG, 2007.

URL: https://www.crisisgroup.org/europe-central-asia/caucasus/nagorno-karabakh-azerbaijan/ nagorno-karabakh-risking-war.

12. Joint Statement on the Nagorno-Karabakh Conflict by the Presidents of the OSCE Minsk Group Co-Chair Countries at the G8 Summit. 16 May 2011. URL: http://www.osce.org/mg/78195.

13. OSCE Handbook. Ed. W.Kemp. - Vienna: OSCE Secretariat, 2000.

14. Preventing a Bloody Harvest on the Armenia-Azerbaijan State Border. ICG Europe Report № 259. Brussels: ICG, 2020. URL: https://www.crisisgroup.org/europe-central-asia/caucasus/nagornokarabakh-conflict/259-preventing-bloody-harvest-armenia-azerbaijan-state-border.

15. Saeedi T. Turkmenistan-Azerbaijan partnership acquires additional features // News Central Asia. 12.03.2020. URL: http://www.newscentralasia.net/2020/03/12/turkmenistan-azerbaijan-partnershipacquires-additional-features.

16. Statement of the OSCE Chairman-in-Office on the Nagorno-Karabakh Conflict. 2-3 December 1996. OSCE Lisbon Summit 1996. Annex 1 of the Lisbon Document. URL: https://www.allgeo.org/ index.php/en/1927-statement-of-the-osce-chairman-in-office-on-the-nagorno-karabakh-conflict-2-3december-1996. 